\title{
Factors affecting colistin nephrotoxicity: Advanced age and/or other factors?
}

\author{
Tugba Arslan Gülen ${ }^{1}$, Ayfer Imre ${ }^{2}$, and Uner Kayabas ${ }^{1}$ \\ ${ }^{1}$ Niğgde Ömer Halisdemir University \\ ${ }^{2}$ Niğde Education and Research Hospital
}

April 15, 2021

\begin{abstract}
Introduction: The population is aging and older adults comprise the majority of patients in intensive care units. Colistin (COL) has been reintroduced to treat increasingly common resistant Gram-negative bacterial infections. Our study aims to investigate the factors affecting colistin nephrotoxicity in the general population and geriatric age group. Materials and Method: This retrospective study included 170 patients, 116 (68.2\%) of which were in the geriatric group (age [?]65). Acute renal failure was evaluated using the RIFLE score. Firstly, factors associated with COL nephrotoxicity in the general population were investigated. Then, risk factors for COL nephrotoxicity were evaluated in the geriatric patient group. Results: Advanced age (odds ratio $[\mathrm{OR}]=1.043 ; 95 \%$ confidence interval $[\mathrm{CI}]: 1.018-1.068 ; \mathrm{p}=0.001)$ and initial serum creatinine level $(\mathrm{OR}=23.122$; 95\% CI: 3.123-171.217; $\mathrm{p}=0.002$ ) were found to be independent risk factors associated with nephrotoxicity. In the evaluation of the geriatric population-based on nephrotoxicity, the initial serum urea and creatinine levels, immunosuppression, and overall mortality rates were found to be statistically significant in the group with nephrotoxicity $(\mathrm{p}<0.05)$. Initial serum creatinine level $(\mathrm{OR}=22.48 ; 95 \% \mathrm{CI}: 2.835-178.426 ; \mathrm{p}=0.003)$ and concomitant nephrotoxic agent use (OR=2.516; 95\% CI: $1.275-4.963$; $\mathrm{p}=0.008)$ were independent risk factors associated with nephrotoxicity in geriatric patients. Conclusion: Advanced age was found to be a risk factor for COL nephrotoxicity. Caution should be exercised especially in geriatric patients who have initial serum creatinine levels close to the upper limit, concomitant use of nephrotoxic drugs should be avoided and if possible, evaluation should be made in terms of non-COL treatment options in these patients.
\end{abstract}

\section{INTRODUCTION}

The number of people aged 65 years and older is increasing globally. With aging, the incidence of chronic disease and malignancy rises, and decline in physiologic and immune functions increases susceptibility to infections (1). Healthcare-associated bacterial infections in old age are particularly alarming because patients over 65 are more frequently hospitalized and subjected to invasive procedures.

There has been a significant increase in infections caused by resistant gram-negative microorganisms. The lack of new drugs effective in the treatment of resistant infections has led to the reintroduction of colistin (COL), which was largely abandoned in clinical practice due to its nephrotoxic and neurotoxic adverse effects $(2-4)$. Being treated in intensive care units (ICUs) and older age are factors that increase the frequency of infections caused by resistant microorganisms and complicate the management of the antimicrobial agents used. Some studies have shown that COL nephrotoxicity increases with age, while no relationship between age and COL-related renal toxicity was detected in others (5-9). The present study aimed to identify risk factors associated with COL nephrotoxicity in the general population and geriatric patients hospitalized in the ICUs of our hospital.

\section{MATERIALS AND METHOD}

\section{Study design and patient population}


The study was planned as a retrospective cohort study and included 170 adult patients (age [?]18 years) who were followed in the ICU and received COL intravenously for documented resistant gram-negative bacterial infections in Niğde Education and Research Hospital between January $1^{\text {st }}, 2012$, and December 31 ${ }^{\text {st }}, 2019$. We investigated risk factors associated with COL nephrotoxicity in general population and geriatric patients.

Exclusion criteria were as follows: having received COL for $<72$ hours; age $<18$ years; pregnancy; and acute and chronic renal failure at the beginning of COL treatment. For patients who had received multiple courses of COL therapy, only the first COL treatment was included in the study analysis.

The pharmaceutical preparation of COL used by the patients was Colimycinß (Kocak Farma, Istanbul, Turkey). One vial contains colistimethate sodium equivalent to $150 \mathrm{mg}$ of COL base activity. A loading dose of $5 \mathrm{mg} / \mathrm{kg}$ was administered to all patients regardless of creatinine clearance. For patients with creatinine clearance [?]70 $\mathrm{mL} / \mathrm{min}$, the total daily dose was calculated as $5 \mathrm{mg} / \mathrm{kg} /$ day and administered in 2 equal doses.

\section{Data collection}

Demographic characteristics, laboratory data, and information regarding comorbidities, concomitant use of nephrotoxic and vasopressor agents were collected retrospectively from infection control committee documents and patients' medical records.

\section{Definitions}

Nephrotoxicity was evaluated according to the RIFLE (Risk, Injury, Failure, Loss, End-stage kidney disease) criteria based on serum creatinine concentrations. According to this system, risk (R) is defined as a 1.5-fold increase in serum creatinine concentration, injury (I) as a 2 -fold increase in serum creatinine concentration, and failure $(\mathrm{F})$ as a 3 -fold increase in serum creatinine or concentration [?]4 $\mathrm{mg} / \mathrm{dL}$; loss (L) is defined as persistent acute renal failure $>4$ weeks and end-stage renal disease $(\mathrm{E})$ is defined as persistent failure $>3$ months (10). Infection was diagnosed according to the criteria defined by the Centers for Disease Control and Prevention (11). Urea and creatinine concentrations on the first day of COL therapy were accepted as initial values. In patients with nephrotoxicity, the dose of COL was adjusted according to creatinine clearance. Urea and creatinine concentrations on the day of discontinuation of COL treatment were evaluated as endof-treatment values.

\section{Statistical analysis}

SPSS Statistics version 18.0 (SPSS Inc. 1989, 2010) software was used to analyze the data. The Shapiro Wilk test was used to assess the normality of data distribution. The homogeneity of variance was evaluated using Levene test. Groups were compared using chi-square or Fisher's exact test for categorical variables, and the independent-samples t-test and Mann-Whitney U test were used for continuous variables. Quantitative variables were shown as mean + - standard deviation (SD) or median (minimum-maximum), and categorical variables as number (n) and percentage (\%). Potential factors for COL nephrotoxicity identified by univariate analyses were analyzed using a multiple logistic regression model. The variables were examined using odds ratio (OD) with $95 \%$ confidence intervals, and p values less than 0.05 were accepted as significant.

Ethics approval: Ethics committee approval was received from Niğde Ömer Halisdemir University Ethics Committee (Reference number: 2018/13-21).

\section{RESULTS}

A total of 170 patients were included in the study (98 men, 57.6\%). The median age was 73 (range, 18-95) years. All patients had infections caused by extremely drug-resistant gram-negative bacterial infections. The causative bacteria were Acinetobacter baumannii (78.2\%), Klebsiella pneumonia (15.9\%), and Pseudomonas aeruginosa $(5.9 \%)$. One hundred eight $(78.2 \%)$ patients had lower respiratory tract infection, $48(28.2 \%)$ had blood stream infection, $8(4.7 \%)$ had surgical site infection, and $6(3.5 \%)$ had urinary tract infection.

Nephrotoxicity was detected in $106(62.4 \%)$ patients. According to the RIFLE classification, 18 (10.6\%) 
patients were evaluated in the 'risk' group, $36(21.2 \%)$ patients in the 'injury' group, and $52(30.6 \%)$ patients in the 'failure' group. Sixty-four patients had no risk factors for the development of nephrotoxicity. Five $(4.7 \%)$ of the patients who developed nephrotoxicity required hemodialysis. Nephrotoxicity classification of elderly and young patients according to the RIFLE score is shown in Figure 1.

The median (minimum-maximum) age of the patients who developed nephrotoxicity was 75 (19-95) and 50\% were male. The duration of hospitalization before COL therapy was similar in patients with and without nephrotoxicity ( $\mathrm{p}=0.109)$. The prevalence of chronic obstructive pulmonary disease (COPD) was significantly higher in the nephrotoxicity group $(\mathrm{p}=0.02)$, but there was no significant difference between the two groups in terms of other comorbid diseases. Initial serum urea and creatinine levels were significantly higher in the nephrotoxicity group $(\mathrm{p}<0.001)$. APACHE II score, vasopressor agent use, concomitant nephrotoxic agent use, 28-day mortality, and overall mortality rates were also higher in the nephrotoxicity group $(\mathrm{p}<0.05)$. The demographic, clinical, and laboratory characteristics of patients based on nephrotoxicity are given in Table 1.

In multivariable logistic regression analysis, advanced age (odds ratio $[\mathrm{OR}]=1.043 ; 95 \%$ confidence interval [CI]: 1.018-1.068; $\mathrm{p}=0.001)$ and initial serum creatinine level $(\mathrm{OR}=23.122 ; 95 \%$ CI: $3.123-171.217 ; \mathrm{p}=0.002)$ were found to be independent risk factors associated with nephrotoxicity (Table 2).

Nephrotoxicity was observed in 88 of the patients aged [?] 65 years. When the patients in the geriatric age group were compared based on nephrotoxicity, the initial serum urea and creatinine values, immunosuppression, concomitant nephrotoxic agent use, and overall mortality rates were found to be statistically higher in patients with nephrotoxicity $(\mathrm{p}<0.05)$ (Table 3$)$. In the same patient group, initial serum creatinine level $(\mathrm{OR}=22.489 ; 95 \% \mathrm{CI}: 2.835-178.426 ; \mathrm{p}=0.003)$ and concomitant nephrotoxic agent use $(\mathrm{OR}=2.516 ; 95 \% \mathrm{CI}$ : 1.275-4.963; $\mathrm{p}=0.008$ ) were identified as independent risk factors associated with nephrotoxicity (Table 4).

Comparison between younger and older patients who developed nephrotoxicity showed that the older group had significantly higher APACHE II score, vasopressor agent use, and 14-day, 28-day, and overall mortality rates $(\mathrm{p}<0.05)$ (Table 5). There was no significance between the two groups in terms of initial and endtreatment serum urea and creatinine levels, concomitant nephrotoxic agent use, and hemodialysis need.

$31.8 \%(\mathrm{n}=54)$ of the cases were in young (age 18-64 years) and $68.2 \%(\mathrm{n}=116)$ were in geriatric group (age [?] 65 years). When the geriatric and younger patients were compared in terms of comorbid diseases, the incidence of COPD and cardiac diseases were significantly higher in the geriatric group $(\mathrm{p}<0.05)$. When nephrotoxicity rates were compared between the younger and geriatric groups, the rate was significantly higher in the geriatric group $(\mathrm{p}<0.001)$. Also, initial serum urea and creatinine, end-treatment urea and creatinine concentrations, APACHE II score, the rate of vasopressor agent use, 14-day, 28-day, and overall mortality rates were found significantly higher in the geriatric group $(\mathrm{p}<0.05)$ (Table 6$)$.

\section{DISCUSSION}

Colistin is a cationic polypeptide-based antimicrobial agent that was first used in the 1950s but was restricted in the 1970s due to its adverse effects (12). The recent dramatic increase in resistant gram-negative bacterial infections has led to the resurgence of COL, especially in ICUs. COL-associated nephrotoxicity remains a major problem in clinical use and the incidence is reported to vary widely, between $11 \%$ and $76 \%(3,7,8,13,14)$. In our study, the acute renal failure rate was determined as $62.4 \%$. Although most of our patients were evaluated as 'failure' or 'injury', only 5 of the patients required hemodialysis. Several factors have been associated with COL nephrotoxicity in the literature, such as higher APACHE II score, hypoalbuminemia, basal serum creatinine concentration, concomitant nephrotoxic drug use, and sex (3,6-8). In the present study, we determined that age, APACHE II score, initial serum creatinine concentration, and rate of concomitant nephrotoxic agent use were higher among patients who developed nephrotoxicity and that the female sex carried a greater risk than the male sex. Similar to our results, there are studies in the literature that identify advanced age as a risk factor for COL nephrotoxicity $(15,16)$.

Most of the patients treated with COL in this study were older patients. Although the rate of COL nephro- 
toxicity was found to be higher in patients with underlying chronic diseases in the studies, when our patient population was evaluated from this point of view, no significant difference was found between the two groups (17). Aydoğan et al. reported higher rates of cardiac disease and COPD in the geriatric group but it was found that advanced age is not a risk factor for nephrotoxicity. (5). In our study, no significant difference was found between geriatric and young patients who developed nephrotoxicity in terms of underlying chronic diseases, concomitant nephrotoxic agent use, initial serum urea and creatinine values. These results have enabled us to evaluate the risk factors associated with nephrotoxicity in geriatric patients more objectively. When the literature is reviewed, there is no study investigating the risk factors associated with colistin nephrotoxicity in the geriatric group, which constitutes the majority of the patient population followed up in the intensive care unit.

We also observed that concomitant use of nephrotoxic agents was more common in the nephrotoxic group in this study. The high incidence of cardiac disease in geriatric patients increases the use of agents such as ACE inhibitors and furosemide in this group. In addition to impaired renal function, hyperkalemia is an important adverse effect of ACE inhibitors (18). Loop diuretics such as furosemide are also frequently used in ICU patients. These agents cause volume depletion with excess diuresis, causing hypotension and acute renal failure. Close monitoring of electrolyte levels and symptoms of hypotension and dehydration is necessary for ICU patients, especially those using concomitant nephrotoxic agents.

Several studies have evaluated the time from COL initiation to the appearance of COL-associated nephrotoxicity. One of these studies showed that nephrotoxicity frequently occurred in the first 72 hours after starting COL (7). In another study investigating COL nephrotoxicity in older and younger adult patients, it was observed that older patients had a significantly longer length of ICU stay before COL initiation (5). When geriatric and young patients were compared in terms of time from onset of COL to nephrotoxicity, there was no statistically significant difference.

Mortality rates are higher among ICU patients due to their advanced age, disease severity, and common healthcare-associated infections. Although some studies demonstrated higher mortality in patients with COL nephrotoxicity, others showed no difference $(3,19,20)$. Özkarakaş et al. reported similar mortality rates between patients with and without nephrotoxicity (19). In another study comparing mortality rates in older and young adult patients receiving COL, there was no difference between the two groups (5). In contrast to these findings, mortality rates were statistically higher in the nephrotoxicity group and in the geriatric nephrotoxicity subgroup in our study.

The average human lifespan is increasing worldwide. According to World Health Organization (WHO) data, the older population is expected to increase from $12 \%$ to $22 \%$ of the total population between 2015 and 2050 (21). Age-related decline in innate immunity brings about changes in neutrophil migration, macrophage phagocytosis, and cytokine production that increase the risk of infection by extracellular pathogens (22). Also, poorer nutrition and hygiene, organ dysfunction, reduced mucociliary activity, and comorbid conditions are other factors that increase the susceptibility to infections in older patients $(1,23,24)$. The majority of patients treated in hospitals are in the geriatric population, especially in ICUs.

In the present study, geriatric patients had higher APACHE II scores, rates of vasopressor agent use, the prevalence of COPD and cardiac disease, and COL nephrotoxicity and mortality rates; and age [?]65 years was found to be an independent risk factor for COL nephrotoxicity. Aging affects the pharmacokinetics and pharmacodynamics of antibiotics (25). Most antibiotics are highly water-soluble and bind to proteins. Antibiotics reach higher concentrations in tissues with high blood flow than in tissues with low blood flow, such as adipose tissue. A decrease in serum proteins such as albumin, lean body mass, and body water and an increase in body fat result in a reduced volume of distribution of antibiotics in older adults. Polypharmacy is common, which also increases the risk of drug-drug interactions in this patient group $(26,27)$. Inadequate administration of antibiotics and failure to perform dose adjustment and follow-up may lead to life-threatening adverse effects. All of these factors increase susceptibility to infection and treatment failure in older patients, especially in ICUs. Therefore, dose adjustment and follow-up should be performed with consideration to the pharmacokinetic and pharmacodynamics of antibiotics. 
COL is mainly excreted renally, and urinary excretion includes renal tubular secretion. It passes through large renal tubular reabsorption (up to 80\%) and most of the filtered COL remains in the body and is therefore mainly cleared by non-renal mechanisms. COL nephrotoxicity is primarily associated with d-aminobutyric acid and fatty acid components, and the mechanism of nephrotoxicity is similar to its antibacterial effect. COL increases the permeability of the tubular epithelial cell membrane, which leads to an influx of cations, anions, and water, leading to cell swelling and consequently to cell lysis (28-30). The dosing regimen of COL should be determined considering the renal function of patients as assessed by creatinine clearance. Especially, care should be exercised in patients with initial serum creatinine levels close to the upper limit, and another treatment option other than COL should be considered in geriatric patients.

In summary, in our study, advanced age was found to be an independent risk factor for COL nephrotoxicity. The high mortality rate in elderly patients treated with COL may be related to the high overall mortality rate of geriatric patients followed in ICUs. Close monitoring of the serum creatinine concentrations and sign of hypovolemia and hypotension of all patients receiving COL treatment is required. If signs and symptoms of renal failure are detected, it is recommended to continue with the required dose adjustment. Vasopressor agent use was found higher in the geriatric group in our study, the reduction of blood circulation to tissues affects the distribution volume of antibiotics. In this respect, it is important that arterial blood pressure monitoring is performed regularly and that the necessary support is given at a sufficient level. Caution should be exercised especially in geriatric patients who have initial serum creatinine levels close to the upper limit or who use concomitant nephrotoxic drugs, and if possible, another treatment option other than COL should be considered in these patients.

Conflicts of interest: The authors declare that they have no conflict of interest.

Funding: This research did not receive any specific grant from funding agencies in the public, commercial, or not-for-profit sectors.

\section{REFERENCES}

1. Crossley KB and Peterson PK. Infections in the Elderly. In: Bennett JE, Dolin R, Blaser MJ (Eds). Mandell, Douglas, and Bennett's Principles and Practice of Infectious Diseases. 8th edition. Philadelphia, Elsevier Saunders; 2015, pp 3459-3465.

2. Justo JA, Bosso JA. Advers reactions associated with systemic polymyxin therapy. Pharmacotherapy 2015; 35(1): 28-33.

3. Hassan MM, Gaifer Z, Al-Zakwani IS. Incidence and risk factors of nephrotoxicity in patients on colistimethate sodium. Int J Clin Pharm 2018; 40(2): 444-449.

4. Biswas S, Brunel JM, Dubus JC, Reynaud-Gaubert M, Rolain JM. Colistin: an update on the antibiotic of the $21^{\text {st }}$ century. Expert Rev Anti Infect Ther 2012; 10(8): 917-934.

5. Aydoğan BB, Yıldırım F, Zerman A, Gönderen K, Türkoğlu M, Aygencel G. Colistin nephrotoxicity in the ICU: Is it different in the geriatric patients? Aging Clin Exp Res 2018; 30: 573-580.

6. Balkan II, Doğan M, Durdu B, et al. Colistin nephrotoxicity inreases with age. Scand J Infect Dis 2014; 46: $678-685$.

7. Miano TA, Lautenbach E, Wilson FP, Guo W, Borovskiy Y, Hennessy S. Attributable Risk and Time Course of Colistin-Associated Acute Kidney Injury. Clin J Am Soc Nephrol 2018; 13(4): 542-550.

8. Kwon KH, Oh JY, Yoon YS, et al. Colistin treatment in carbapenem-resistant Acinetobacter baumannii pneumonia patients: Incidence of nephrotoxicity and outcomes. Int J Antimicrob Agents 2015; 45(6): 605609.

9. Kim J, Lee KH, Yoo S, Pai H. Clinical characteristics and risk factors of colistin-induced nephrotoxicity. Int J Antimicrob Agents 2009; 34(5): 434-438. 
10. Venkataraman R, Kellum JA. Defining acute renal failure: the RIFLE criteria. J Intensive Care Med 2007; 22(4): 187-193.

11. Horan T, Andrus M, Dudeck M. CDC/NHSN surveillance definition of health care associated infection and criteria for specific types of infections in the acute care setting. Am J Infect Control 2008; 36: 309-332.

12. Avedissian SN, Liu J, Rhodes NJ, et al. A Review of the Clinical Pharmacokinetics of Polymyxin B. Antibiotics (Basel). 2019 Mar 22;8(1):31.

13. Tuon FF, Rigatto MH, Lopes CK, Kamei LK, Rocha JL, Zavascki AP. Risk factors for acute kidney injury in patients treated with polymyxin B or colistin methanesulfonate sodium. Int J Antimicrob Agents 2014; 43(4): 349-352.

14. Khawcharoenporn T, Pruetpongpun N, Tiamsak P, Rutchanawech S, Mundy LM, Apisarnthanarak A. Colistin-based treatment for extensively drug-resistant Acinetobacter baumannii pneumonia. Int J Antimicrob Agents 2014; 43(4): 378-382.

15. Al-Abdulkarim DA, Alzuwayed OA, Al Ammari M, Al Halwan S, Al Maklafi N, Thomas A. Colistininduced Nephrotoxicity in a Tertiary Teaching Hospital. Saudi J Kidney Dis Transpl. 2020 SepOct;31(5):1057-1061.

16. Gunay E, Kaya S, Baysal B, Yuksel E, Arac E. Evaluation of prognosis and nephrotoxicity in patients treated with colistin in intensive care unit. Ren Fail. 2020 Nov;42(1):704-709.

17. Doshi NM, Mount KL, Murphy CV. Nephrotoxicity associated with intravenous colistin in critically ill patients. Pharmacotherapy. 2011 Dec;31(12):1257-64.

18. Busca C, Moga DC, Farcas A, Mogosan C, Dumitrascu DL. An investigation of the concomitant use of anjiotensin-converting enzyme inhibitors, non-steroidal anti-inflammatory drugs and diuretics. Eur Rev Med Pharmacol Sci 2015; 19(15): 2938-44.

19. Özkarakaş H, Köse I, Zincircioğlu Ç, et al. Risk factors for colistin-associated nephrotoxicity and mortality in critically ill patients. Turk J Med Sci 2017 Aug 23;47(4): 1165-1172.

20. Koksal I, Kaya S, Gencalioglu E, Yilmaz G. Evaluation of risk factors for intravenous colistin use-related nephrotoxicity. Oman Med J 2016 Jul; 31(4): 318-21.

21. Ageing and health. Available from:https://www.who.int/news-room/fact-sheets/detail/ageing-andhealthAccessed: 10 April 2019.

22. Kline KA, Bowdish DM. Infection in an aging population. Curr Opin Microbiol. 2016 Feb; 29:63-67.

23. Marik PE, Kaplan D. Aspiration pneumonia and dysphagia in the elderly. Chest. 2003 Jul;124(1):328-336.

24. Liang SY. Sepsis and Other Infectious Disease Emergencies in the Elderly. Emerg Med Clin North Am. 2016 Aug;34(3):501-522.

25. Udy AA, Roberts JA, Lipman J. Clinical implications of antibiotic pharmacokinetic principles in the critically ill. Intensive Care Med. 2013 Dec;39(12):2070-82.

26. Bradley SF. Principles of Antimicrobial Therapy in Older Adults. Clin Geriatr Med. 2016 Aug;32(3):44357.

27. Pagani L. Appropriate antimicrobial therapy in the elderly: when half-size does not fit all frail patients. Clin Microbiol Infect. 2015 Jan;21(1):1-2.

28. Karaiskos I, Souli M, Galani I, Giamarellou H. Colistin: still a lifesaver for the 21st century? Expert Opin Drug Metab Toxicol. 2017 Jan;13(1):59-71.

29. Grégoire N, Aranzana-Climent V, Magréault S, Marchand S, Couet W. Clinical Pharmacokinetics and Pharmacodynamics of Colistin. Clin Pharmacokinet. 2017 Dec;56(12):1441-1460. 
30. Ordooei Javan A, Shokouhi S, Sahraei Z. A review on colistin nephrotoxicity. Eur J Clin Pharmacol. 2015 Jul; $71(7): 801-10$.

Table 1. Demographic, clinical, and laboratory features of all patients according to nephrotoxicity

\begin{tabular}{|c|c|c|c|}
\hline Variables & $\begin{array}{l}\text { Nephrotoxicity }(+) \\
\mathrm{n}=106(62.4 \%)\end{array}$ & $\begin{array}{l}\text { Nephrotoxicity }(-) \mathrm{n}=64 \\
(37.6 \%)\end{array}$ & $\mathrm{p}$ value \\
\hline $\begin{array}{l}\text { Age, median } \\
\text { (min-max) }\end{array}$ & $75(19-95)$ & $62(18-92)$ & $<0.001$ \\
\hline Sex, n (\%) Male Female & $53(50) 53(50)$ & $45(70.3) 19(29.7)$ & 0.009 \\
\hline $\begin{array}{l}\text { Duration of } \\
\text { hospitalization before } \\
\text { COL therapy, median } \\
\text { (min-max) }\end{array}$ & $18(3-101)$ & $14.5(4-52)$ & 0.109 \\
\hline $\begin{array}{l}\text { APACHE II } \\
(\text { mean } \pm \text { SD })\end{array}$ & $25.17 \pm 6.8$ & $21.94 \pm 7.85$ & 0.007 \\
\hline $\begin{array}{l}\text { Underlying Diseases, } \mathrm{n} \\
\text { (\%) Chronic }\end{array}$ & $\begin{array}{l}61(57.5) 30(28.3) 24 \\
(22.6) 30(28.3) 7(6.6)\end{array}$ & $\begin{array}{l}25(39.1) 14(21.9) 9 \\
(14.1) 10(15.6) 7\end{array}$ & $\begin{array}{llll}\mathbf{0 . 0 2} & 0.354 & 0.171 & 0.059 \\
0.319 & 1.0\end{array}$ \\
\hline $\begin{array}{l}\text { Obstructive Pulmonary } \\
\text { Disease (COPD) }\end{array}$ & $3(2.8)$ & $(10.9) 1(1.6)$ & \\
\hline Diabetes mellitus (DM) & & & \\
\hline Cardiac failure $(\mathrm{CF})$ & & & \\
\hline $\begin{array}{l}\text { Coronary artery } \\
\text { disease (CAD) }\end{array}$ & & & \\
\hline Immunosuppression & & & \\
\hline Solid organ malignancy & & & \\
\hline $\begin{array}{l}\text { Initial serum urea } \\
(\mathrm{mg} / \mathrm{dL}) \text { median } \\
(\min -\max )\end{array}$ & $46(16-125)$ & $39.5(9-87)$ & 0.02 \\
\hline $\begin{array}{l}\text { Initial serum creatinine } \\
(\mathrm{mg} / \mathrm{dL}) \text { median } \\
(\mathrm{min}-\max )\end{array}$ & $0.8(0.34-1.2)$ & $0.63(0.3-1.2)$ & $<0.001$ \\
\hline $\begin{array}{l}\text { End-treatment serum } \\
\text { urea }(\mathrm{mg} / \mathrm{dL}) \text { median } \\
(\min -\max )\end{array}$ & $116(35-295)$ & $43.5(8-169)$ & $<0.001$ \\
\hline $\begin{array}{l}\text { End-treatment serum } \\
\text { creatinine }(\mathrm{mg} / \mathrm{dL}) \\
\text { median }(\min -\mathrm{max})\end{array}$ & $2.46(0.73-8)$ & $0.72(0.21-1.5)$ & $<0.001$ \\
\hline Concomitant & $78(73.6) 19(17.9) 14$ & $34(53.1) 6(9.4) 8$ & $\mathbf{0 . 0 0 6} 0.1270 .8940 .524$ \\
\hline nephrotoxic agent use, & $(13.2) 3(2.8) 1(0.94) 2$ & $(12.5) 3(4.7) 1(1.6) 1$ & $\begin{array}{llll}0.716 & 0.876 & 0.295 & 0.716\end{array}$ \\
\hline n (\%) Sulbactam & (1.9) $1(0.94) 1(0.94) 3$ & $(1.6) 2(3.1) 1(1.6) 2$ & $0.9120 .716 \mathbf{0 . 0 1 2}$ \\
\hline Vancomycin NSAID & $(2.8) 1(0.94) 33(31.1)$ & (3.1) $1(1.6) 9$ (14.1) & \\
\hline NSAID+Sulbactam & & & \\
\hline \multicolumn{4}{|c|}{ NSAID + Sulbactam + Amikacin } \\
\hline \multicolumn{4}{|l|}{ ACEI+Sulbactam AG } \\
\hline \multicolumn{4}{|l|}{ ACEI+ARB AMPHOb } \\
\hline Furosemide & & & \\
\hline $\begin{array}{l}\text { Vasopressor agent use, } \\
\mathrm{n}(\%)\end{array}$ & $60(56.6)$ & $26(40.6)$ & 0.043 \\
\hline 14-day mortality, n (\%) & $50(47.2)$ & $22(34.4)$ & 0.102 \\
\hline 28-day mortality, n (\%) & $37(34.9)$ & $18(28.1)$ & 0.029 \\
\hline
\end{tabular}




\begin{tabular}{llll}
\hline Variables & $\begin{array}{l}\text { Nephrotoxicity }(+) \\
\mathrm{n}=106(62.4 \%)\end{array}$ & $\begin{array}{l}\text { Nephrotoxicity }(-) \mathrm{n}=64 \\
(37.6 \%)\end{array}$ & $\mathrm{p}$ value \\
\hline $\begin{array}{l}\text { Overall mortality, } \mathrm{n} \\
(\%)\end{array}$ & $98(92.5)$ & $44(68.8)$ & $<\mathbf{0 . 0 0 1}$ \\
\hline
\end{tabular}

NSAID: Nonsteroidal anti-inflammatory drug, ACEI: Angiotensin converting enzyme inhibitor, AG: Aminoglycosides ARB: Angiotensin receptor blocker AMPHOb: Amphotericin B

Table 2. Logistic regression analyses of risk factors for colistin nephrotoxicity

\begin{tabular}{lllll}
\hline & Univariate Analyses & Univariate Analyses & Univariate Analyses & Multivari \\
\hline & $p$ value & Odds Ratio & $\mathbf{9 5 \%}$ Confidence Interval & $p$ value \\
Age & $<\mathbf{0 . 0 0 1}$ & 1.052 & $1.030-1.075$ & $\mathbf{0 . 0 0 1}$ \\
Sex (Female) & 0.01 & 0.422 & $0.219-0.815$ & 0.435 \\
APACHE II Score & $\mathbf{0 . 0 0 6}$ & 1.064 & $1.017-1.112$ & \\
COPD $(+)$ & 0.02 & 0.473 & $0.251-0.890$ & $\mathbf{0 . 0 0 2}$ \\
Initial serum creatinine $(\mathrm{mg} / \mathrm{dL})$ & $<\mathbf{0 . 0 0 1}$ & 40.320 & $6.389-254.465$ & 0.02 \\
Concomitant nephrotoxic agent use & $\mathbf{0 . 0 0 1}$ & 3.057 & $1.598-5.849$ & \\
\hline
\end{tabular}

COPD: Chronic obstructive pulmonary disease

Table 3. Nephrotoxicity based assessment in geriatric patients

\begin{tabular}{|c|c|c|c|}
\hline Variables & $\begin{array}{l}\text { Nephrotoxicity }(+) \\
\mathrm{n}=\mathbf{8 8}\end{array}$ & $\begin{array}{l}\text { Nephrotoxicity (-) } \\
\mathbf{n}=\mathbf{2 8}\end{array}$ & $p$ value \\
\hline Sex, n (\%) Female Male & $47(53.4) 41(46.6)$ & $11(39.3) 17(60.7)$ & 0.193 \\
\hline $\begin{array}{l}\text { APACHE } \\
\mathrm{II}^{*}(\operatorname{mean} \pm \mathrm{SD})\end{array}$ & $25.78 \pm 6.542$ & $25.64 \pm 6.86$ & 0.922 \\
\hline $\begin{array}{l}\text { Duration of } \\
\text { hospitalization before } \\
\text { COL therapy, median } \\
(\min -\max )\end{array}$ & $18(3-101)$ & $14(4-31)$ & 0.094 \\
\hline $\begin{array}{l}\text { Initial serum urea } \\
(\mathrm{mg} / \mathrm{dL})(\text { mean } \pm \mathrm{SD})\end{array}$ & $52.42 \pm 23.01$ & $42.18 \pm 18.59$ & 0.034 \\
\hline $\begin{array}{l}\text { Initial serum creatinine } \\
(\mathrm{mg} / \mathrm{dL}) \text { median } \\
(\mathrm{min}-\mathrm{max})\end{array}$ & $0.8(0.34-1.2)$ & $0.64(0.3-0.95)$ & 0.001 \\
\hline $\begin{array}{l}\text { Total colistin day, } \\
\text { median (min-max) }\end{array}$ & $10(4-23)$ & $8.5(4-18)$ & 0.141 \\
\hline $\begin{array}{l}\text { Underlying diseases, } \mathrm{n} \\
(\%) \text { Chronic } \\
\text { obstructive pulmonary } \\
\text { disease Diabetes } \\
\text { mellitus Coronary } \\
\text { artery disease Cardiac } \\
\text { failure Chronic renal } \\
\text { failure } \\
\text { Immunosupression } \\
\text { Solid organ malignancy }\end{array}$ & $\begin{array}{l}53(60.2) 23(26.1) 27 \\
(30.7) 23(26.1) 4(4.5) \\
2(2.3)\end{array}$ & $\begin{array}{l}16(57.1) 9(32.1) 8 \\
(28.6) 7(25) 1(3.6) 4 \\
(14.3)\end{array}$ & $\begin{array}{l}0.7720 .5360 .8320 .905 \\
1 \mathbf{0 . 0 2 3}\end{array}$ \\
\hline
\end{tabular}




\begin{tabular}{llll}
\hline Variables & $\begin{array}{l}\text { Nephrotoxicity }(+) \\
\mathbf{n = 8 8}\end{array}$ & $\begin{array}{l}\text { Nephrotoxicity }(-) \\
\mathbf{n = 2 8}\end{array}$ & p value \\
\hline $\begin{array}{l}\text { Vasopressor agent use, } \\
\text { n (\%) }\end{array}$ & $33(37.5)$ & $10(35.7)$ & 0.865 \\
$\begin{array}{l}\text { Concomitant } \\
\text { nephrotoxic agent use, } \\
\text { n (\%) }\end{array}$ & $25(28.4)$ & $14(50)$ & $\mathbf{0 . 0 3 5}$ \\
$\begin{array}{l}\text { 14-day mortality } \\
\text { 28-day mortality }\end{array}$ & $46(52.3)$ & $14(50)$ & \\
Overall mortality & $31(73.8)$ & $9(64.3)$ & 0.865 \\
\hline
\end{tabular}

Table 4. Independent risk factors associated with nephrotoxicity in the geriatric group

\begin{tabular}{lllll}
\hline & Univariate Analyses & Univariate Analyses & Univariate Analyses & Multivari \\
\hline & $p$ value & Odds Ratio & $\mathbf{9 5 \%}$ Confidence Interval & $p$ value \\
Initial serum urea $(\mathrm{mg} / \mathrm{dL})$ & $\mathbf{0 . 0 1}$ & 1.021 & $1.005-1.038$ & 0.493 \\
Initial serum creatinine $(\mathrm{mg} / \mathrm{dL})$ & $<\mathbf{0 . 0 0 1}$ & 40.320 & $6.389-254.465$ & $\mathbf{0 . 0 0 3}$ \\
Immunosupression & 0.324 & 1.737 & $0.580-5.203$ & \\
Concomitant nephrotoxic agent use & $\mathbf{0 . 0 0 1}$ & 3.057 & $1.598-5.849$ & $\mathbf{0 . 0 0 8}$ \\
\hline
\end{tabular}

Table 5. Age-based clinical and laboratory characteristics of patients with colistin nephrotoxicity

\begin{tabular}{|c|c|c|c|}
\hline & $18-64$ years $n=18(16.2 \%)$ & [?] 65 years $n=88(83 \%)$ & $\mathrm{p}$ value \\
\hline $\begin{array}{l}\text { APACHE II } \\
(\text { mean } \pm \text { SD })\end{array}$ & $22.17 \pm 7.61$ & $25.78 \pm 6.542$ & 0.04 \\
\hline $\begin{array}{l}\text { Duration of } \\
\text { hospitalization before } \\
\text { COL therapy, median } \\
\text { (min-max) }\end{array}$ & $17(5-43)$ & $18(3-101)$ & 0.930 \\
\hline $\begin{array}{l}\text { Initial serum urea } \\
(\mathrm{mg} / \mathrm{dL}) \text { median } \\
(\min -\max )\end{array}$ & $36(20-99)$ & $52(16-125)$ & 0.081 \\
\hline $\begin{array}{l}\text { Initial serum creatinine } \\
(\mathrm{mg} / \mathrm{dL})(\text { mean } \pm \mathrm{SD})\end{array}$ & $0.74 \pm 0.191$ & $0.78 \pm 0.204$ & 0.424 \\
\hline $\begin{array}{l}\text { End-treatment serum } \\
\text { urea }(\mathrm{mg} / \mathrm{dL}) \text { median } \\
(\mathrm{min}-\mathrm{max})\end{array}$ & $85.5(36-266)$ & $117.5(43-295)$ & 0.089 \\
\hline $\begin{array}{l}\text { End-treatment serum } \\
\text { creatinine }(\mathrm{mg} / \mathrm{dL}) \\
\text { median }(\min -\max )\end{array}$ & $2.34(0.73-5.68)$ & $2.56(1-8)$ & 0.970 \\
\hline $\begin{array}{l}\text { Total colistin day, } \\
\text { median (min-max) }\end{array}$ & $14(5-22)$ & $10(4-23)$ & 0.123 \\
\hline $\begin{array}{l}\text { Colistin toxicity day, } \\
\text { median (min-max) }\end{array}$ & $7.5(2-19)$ & $5(2-18)$ & 0.236 \\
\hline
\end{tabular}




\begin{tabular}{|c|c|c|c|}
\hline & $18-64$ years $n=18(16.2 \%)$ & [?] 65 years $\mathrm{n}=88(83 \%)$ & $\mathrm{p}$ value \\
\hline $\begin{array}{l}\text { Underlying diseases, } \mathrm{n} \\
\text { (\%) Chronic } \\
\text { obstructive pulmonary } \\
\text { disease Diabetes } \\
\text { mellitus Coronary } \\
\text { artery disease Cardiac } \\
\text { failure } \\
\text { Immunosupression } \\
\text { Solid organ malignancy }\end{array}$ & $\begin{array}{l}8(44.4) 7(38.9) 3 \\
(16.7) 1(5.6) 5(27.8) 0 \\
(0.0)\end{array}$ & $\begin{array}{l}53(60.2) 23(26.1) 27 \\
(30.7) 23(26.1) 2(2.3) \\
3(3.4)\end{array}$ & $\begin{array}{l}0.2170 .2740 .2290 .067 \\
\mathbf{0 . 0 0 1} 1.00\end{array}$ \\
\hline $\begin{array}{l}\text { Vasopressor agent use, } \\
\text { n (\%) }\end{array}$ & $5(27.8)$ & $55(62.5)$ & 0.009 \\
\hline $\begin{array}{l}\text { Concomitant } \\
\text { nephrotoxic agent use, } \\
\text { n (\%) }\end{array}$ & $13(72.2)$ & $63(71.6)$ & 0.957 \\
\hline $\begin{array}{l}\text { Need for hemodialysis, } \\
\mathrm{n}(\%)\end{array}$ & $1(5.6)$ & $4(4.5)$ & 1.00 \\
\hline 14-day mortality, n (\%) & $4(22.2)$ & $46(52.3)$ & 0.02 \\
\hline 28-day mortality, n (\%) & $6(40)$ & $31(73.8)$ & 0.019 \\
\hline $\begin{array}{l}\text { Overall mortality, } \mathrm{n} \\
(\%)\end{array}$ & $14(77.8)$ & $84(95.5)$ & 0.027 \\
\hline
\end{tabular}

Table 6. Demographic, clinical, and laboratory features of all patients according to age groups

\begin{tabular}{|c|c|c|c|}
\hline Variables & $18-64$ years $\mathrm{n}=54(31.8 \%)$ & $\begin{array}{l}{[?] 65 \text { years } \mathrm{n}=116} \\
(68.2 \%)\end{array}$ & $\mathrm{p}$ value \\
\hline Sex, n (\%) Female Male & $14(25.9) 40(74.1)$ & $58(50) 58(50)$ & 0.003 \\
\hline $\begin{array}{l}\text { APACHE II } \\
(\text { mean } \pm \text { SD })\end{array}$ & $20.9 \pm 7.6$ & $25.74 \pm 6.6$ & $<0.001$ \\
\hline $\begin{array}{l}\text { Underlying diseases, } \mathrm{n} \\
\text { (\%) Chronic }\end{array}$ & $\begin{array}{l}17(31.5) 12(22.2) 3 \\
(5.6) 5(9.3) 8(14.8) 1\end{array}$ & $\begin{array}{l}69(59.5) 32(27.6) 30 \\
(25.9) 35(30.2) 6(5.2)\end{array}$ & $\begin{array}{lll}\mathbf{0 . 0 0 1} & 0.457 & \mathbf{0 . 0 0 2} \\
\mathbf{0 . 0 0 3} & 0.067 & 1.0\end{array}$ \\
\hline $\begin{array}{l}\text { obstructive pulmonary } \\
\text { disease Diabetes } \\
\text { mellitus Cardiac failure } \\
\text { Coronary artery disease } \\
\text { Immunosuppression } \\
\text { Solid organ malignancy }\end{array}$ & $(1.9)$ & $3(2.6)$ & \\
\hline $\begin{array}{l}\text { Initial serum urea } \\
(\mathrm{mg} / \mathrm{dL}) \text { median } \\
(\mathrm{min}-\mathrm{max})\end{array}$ & $39(11-99)$ & $48(9-125)$ & 0.041 \\
\hline $\begin{array}{l}\text { Initial serum creatinine } \\
(\mathrm{mg} / \mathrm{dL}) \text { median } \\
(\mathrm{min}-\mathrm{max})\end{array}$ & $0.65(0.3-1.2)$ & $0.77(0.3-1.2)$ & 0.018 \\
\hline $\begin{array}{l}\text { COL nephrotoxicity, n } \\
(\%)\end{array}$ & $18(33.3)$ & $88(75.9)$ & $<0.001$ \\
\hline $\begin{array}{l}\text { Concomitant } \\
\text { nephrotoxic agent use, } \\
\text { n (\%) }\end{array}$ & $28(50.3)$ & $83(65.9)$ & 0.07 \\
\hline $\begin{array}{l}\text { Vasopressor agent use, } \\
\mathrm{n}(\%)\end{array}$ & $13(24.1)$ & $73(62.9)$ & $<0.001$ \\
\hline
\end{tabular}




\begin{tabular}{|c|c|c|c|}
\hline Variables & $18-64$ years $n=54(31.8 \%)$ & $\begin{array}{l}{[?] 65 \text { years } \mathrm{n}=116} \\
(68.2 \%)\end{array}$ & $\mathrm{p}$ value \\
\hline $\begin{array}{l}\text { End-treatment serum } \\
\text { urea }(\mathrm{mg} / \mathrm{dL}) \text { median } \\
(\min -\mathrm{max})\end{array}$ & $49(8-266)$ & $93.5(10-295)$ & $<0.001$ \\
\hline $\begin{array}{l}\text { End-treatment serum } \\
\text { creatinine }(\mathrm{mg} / \mathrm{dL}) \\
\text { median }(\min -\max )\end{array}$ & $0.83(0.21-5.68)$ & $1.96(0.3-8)$ & $<0.001$ \\
\hline 14-day mortality, n (\%) & $12(22.2)$ & $60(51.7)$ & $<0.001$ \\
\hline 28-day mortality, n (\%) & $15(34.9)$ & $40(71.4)$ & $<0.001$ \\
\hline $\begin{array}{l}\text { Overall mortality, } \mathrm{n} \\
(\%)\end{array}$ & $35(64.8)$ & $107(92.2)$ & $<0.001$ \\
\hline
\end{tabular}

Figure legend: Figure 1. Age-based nephrotoxicity rates according to RIFLE score

\section{Hosted file}

FigureCOL.pptx available at https://authorea.com/users/375182/articles/518095-factorsaffecting-colistin-nephrotoxicity-advanced-age-and-or-other-factors 